\title{
PERAN BADAN PERTANAHAN NASIONAL DALAM PENYELESAIAN SENGKETA KEPEMILIKAN TANAH
}

\author{
Hizkia Natasha Hutabarat, Erita Wagewati Sitohang, Tulus Siambaton \\ Fakultas Hukum, Universitas HKBP Nommensen \\ eritawagewatisihotang@uhn.ac.id
}

\begin{abstract}
Abstrak
Badan Pertanahan Nasional dalam penyelesaian sengketa kepemilikan tanah dan untuk mengetahui bagaimana tindakan pihak yang bersengketa atas peran Badan Pertanahan Nasional. Metode pengumpulan data yang dilakukan adalah dengan wawancara dengan Kepala Seksi Penanganan Masalah dan Pengendalian Pertanahan di Kantor Pertanahan Kabupaten Tapanuli Utara. Hasil penelitian menunjukkan bahwa peran Badan Pertanahan Nasional dalam penyelesaian sengketa kepemilikan tanah dengan menerima pengaduan masyarakat, kemudian mengumpulan data dan menganalisis sengketa, serta mengkaji dan melakukan pemeriksaan lapangan. Kemudian menerbitkan keputusan penyelesaian sengketa berupa Keputusan Pembatalan Hak atau Keputusan Pembatalan Sertipikat apabila terbukti terdapat cacat adminstrasi. Selain itu memfalitasi mediasi kepada pihak yang bersengketa apabila sengketa memungkinkan untuk diadakan mediasi. Tindakan pihak yang bersengketa atas peran Badan Pertanahan Nasional dalam penyelesaian sengketa yaitu menyepakati dan/atau menolak. Dalam hal menolak penyelesaian yang dilakukan di Kantor Pertanahan,berarti sengketa tidak berhasil diselesaikan, kedua belah pihak tidak dapat menghasilkan kesepakatan. Penyelesaian yang dilakukan di Kantor Badan Pertanahan Nasional tidak berhasil diselesaikan, maka penyelesaiannya diserahkan kepada para pihak yang bersengketa sesuai dengan ketentuan perundang-undangan.
\end{abstract}

Kata Kunci : sengketa, kepemilikan tanah, badan pertanahan nasional

\begin{abstract}
National Land Agency in resolving land ownership disputes and to find out how the disputing parties act on the role of the National Land Agency. The results showed that the role of the National Land Agency in resolving land ownership disputes by receiving complaints from the public, then collecting data and analyzing disputes, as well as reviewing and conducting field inspections. In addition, facilitating mediation to the disputing parties if the dispute allows for mediation. The disputing parties' actions on the role of the National Land Agency in dispute resolution are agreeing or rejecting. In agreeing, it means that the dispute has been successfully resolved, the parties have succeeded in finding an agreement, uniting their opinions and interests, which in the end is a binding Peace Agreement for both parties. In the case of refusing a settlement made at the Land Office, it means that the dispute has not been resolved successfully, both parties cannot produce an agreement. The settlement made at the Office of the National Land Agency is not successful, so the settlement is submitted to the disputing parties in accordance with statutory provisions.
\end{abstract}

Keywords: dispute, land ownership, national land agency 


\section{PATIK : JURNAL HUKUM Vol : 10 No. 1 April 2021, Hal 61 - 68}

\section{Pendahuluan}

Tanah merupakan salah satu sumber daya alam yang dikaruniakan Tuhan Yang Maha Esa. Tanah merupakan kebutuhan hidup manusia yang paling mendasar sebab manusia hidup dan berkembang biak serta melakukan aktivitas diatas tanah. Tanah juga berperan penting sebagai sumber penghidupan dan mata pencaharian. Indonesia sebagai salah satu negara yang sebagian besar rakyatnya menggantungkan hidup pada sektor agraris baik dalam usaha perkebunan, pertanian dan lain sebagainya. Tanah dan manusia tidak dapat dipisahkan dari semenjak manusia lahir hingga manusia meninggal dunia. Tanah diatur dalam Undang-Undang Nomor 5 Tahun 1960 tentang Peraturan Dasar PokokPokok Agraria, yang lebih dikenal dengan sebutan Undang-Undang Pokok Agraria (UUPA).Pasal 19 ayat (1) Undang-Undang Pokok Agraria (UUPA) menyebutkan "Untuk menjamin kepastian hukum oleh pemerintah diadakan pendaftaran tanah di seluruh wilayah Republik Indonesia menurut ketentuan - ketentuan yang diatur dengan Peraturan Pemerintah".

Untuk memberikan kepastian dan perlindungan hukum kepada pemegang hak atas tanah yang bersangkutan diberikan sertipikat hak atas tanah.Sertipikat adalah surat tanda bukti hak untuk hak atas tanah, hak pengelolaan, tanah wakaf, hak milik atas satuan rumah susun dan hak tanggungan yang masing-masing sudah dibukukan dalam buku tanah yang bersangkutan.Sertipikat merupakan surat tanda bukti hak yang berlaku sebagai alat pembuktian yang kuat mengenai data fisik dan data yuridis yang termuat di dalamnya, sepanjang data fisik dan data yuridis tersebut sesuai dengan data yang ada dalam surat ukur dan buku tanah hak yang bersangkutan.

Indonesia menganut sistem pendaftaran negative (stelsel negatif) bertendensi positif, dimana pemerintah tidakmemberikan jaminan atas kepastian hukum terhadap pemegang bukti sah (sertipikat). Pemerintah juga tidak bertanggung jawab atas data dan informasi yang ada di dalam sertifikat hak atas tanah. Data dan informasi dianggap benarsepanjang tidak ada pihak lain yang menggugat. Kondisi demikian menyebabkan timbulnya berbagai masalah, sehingga didalam praktek pendaftaran tanah tersebut,banyak orang yang mendaftarkan tanah diatas tanah yang bukan miliknya pribadi namun milik bersama yang merupakan tanah warisan. Hal ini tak jarang dilatar belakangi oleh pemilik yang sesungguhnya berada diluar kota dan meninggalkan tanahnya dikampung tanpa mendaftarkan tanahnya namun beberapa tahun kemudian disaat semakin pentingnya tanah dan harga tanah semakin naik maka pemilik tanah yang sesungguhnya berniat mendaftarkan tanahnya ke Badan Pertanahan Nasional (BPN) agar memperoleh setipikat, namun kenyataannya tanah tersebut telah didaftarkan dan telah terbit sertipikat atas tanah tersebut, yang di lakukan oleh pihak lain atau kerabat lain dari pemilik sesungguhnya.

Fenomena seperti ini banyak ditemui di Kabupaten Tapanuli Utara, terutama di Kecamatan Siborong-borong Silangit, hal ini dipicu oleh Bandara Silangit yang diperbaharui menjadi bandara Internasional Tahun 2018 silam, maka secara otomatis harga tanah semakin meningkat didaerah tersebut sehinggamasyarkat dikota yang dulunya menelantarkan tanahnya dikampung, atau menitipkan kepada kerabatnya menjadi menyadari betapa pentingnya tanah. Hal ini juga yang mengakibatkan sengketa terhadap tanahsemakin meningkat.Tercatat sejak tahun 2018 - 2020 sengketa tanah di Kantor Pertanahan Nasional Kabupaten Tapanuli Utara mengalami peningkatan diberbagai desadesa di Kabupaten Tapanuli Utara.

Dalam hal terjadi sengketa hak kepemilikan atas tanah, maka pihak yang merasa memiliki tanah tentu akan berusaha keras memperjuangkan hak-haknya. Pihak yangbersangkutan dapat mengajukan pengaduan ke Badan Pertanahan Nasional (BPN)yang isinya adalah keberatan-keberatan dan tuntutan hak atas tanah baik terhadap 


\section{PATIK : JURNAL HUKUM Vol : 10 No. 1 April 2021, Hal 61 - 68}

status tanah, proritas kepemilikan dan harapan dapat memperoleh penyelesaian sesuai dengan ketentuan yang berlaku.

Badan Pertanahan Nasional (BPN) selaku penyelenggara dibidang pertanahan dan badan yang menerbitkan sertipikat tentu mempunyai tanggung jawab terhadap sertipikat yang dikeluarkannya. Penyelesaian sengketa tanah dapat dilakukan melalui 2 (dua) cara yaitu litigasi dan non litigasi. Namun penyelesaian secara litigasi membutuhkan jangka waktu yang lama. Maka dalam hal ini diperlukan peranan Badan Pertanahan Nasional (BPN) untuk memberikan penyelesaian secara non litigasi berupa mediasi dan fasilitasi kepada pihak yang bersengketa agar mencapai kesepakatan tanpa harus melalu proses litigasi/pengadilan. Berdasarkan latar belakang yang telah diuraikan diatas, maka permasalahan yang akan diteliti adalah :

1) Bagaimana peran Badan Pertanahan Nasional dalam penyelesaian sengketa kepemilikan tanah?

2) Bagaimana tindakan pihak yang bersengketa atas peran Badan Pertanahan Nasional?

\section{Tinjauan Pustaka}

Pasal 1 Peraturan Presiden Nomor 20 Tahun 2015 tentang Badan Pertanahan Nasional memberikan pengertian Badan Pertanahan Nasional yang selanjutnya disebut BPN adalah lembaga pemerintah non kementerian yang berada dibawah dan bertanggungjawab kepada Presiden, yang melaksanakan tugas pemerintahan di bidang pertanahan sesuai dengan ketentuan peraturan perundang undangan. Pasal 2 Peraturan Presiden Nomor 20 Tahun 2015 menyebutkan bahwa Badan Pertanahan Nasional (BPN) mempunyai tugas yaitu melaksanakan tugas pemerintah dibidang pertanahan sesuai dengan ketentuan peraturan perundang-undangan.

Pasal 1 PP No 24 Tahun 1997 tentang Pendaftaran Tanah, memberikan pengertian pendaftaran tanah adalah rangkaian yang dilakukan oleh Pemerintah secara terusmenerus, bersekinambungan dan teratur, meliputi pengumpulan, pengelolaan,pembukaan dan pengajian serta pemeliharan data fisik dan data yuridis, dalam bentuk peta dan daftar, mengenai bidang-bidang tanah yang sudah ada haknya dan hak milikatas satuan rumah susun serta hak-hak tertentu yang membebaninya.Pendaftaran tanah berarti mencatat hakhak yang dipegang dan dimiliki oleh seorang,baik itu perorangan atau kelompok ataupun suatu lembaga atas sebidang tanah olehPejabat yang berwenang dan karenanya berhak untuk mengeluarkan suatu surat buktihak atas kepemilikannya tersebut.

Kegiatan pendaftaran tanah dilaksanakan berdasarkan ketentuan yang terdapat dalam Pasal 12 PP No 24 Tahun 1997. Di dalam pasal tersebut menjelaskan tentang kegiatan-kegiatan yang dilakukanpada saat pendaftaran tanah untuk pertama kali meliputi:

a) Pengumpulan dan Pengolahan Data Fisik.

Pengumpulan dan pengolahan data fisik dilakukan melalui kegiatan pengukurandan pemetaan, kegiatan tersebut meliputi: pembuatan peta dasar pendaftaran,penetapan batas-batas bidang tanah, dan pengukuran dan pemetaan bidang-bidangtanah serta pembuatan peta pendaftaran, pembuatan daftar tanah, pembuatan suratukur.

b) Pembuktian hak dan pembukuannya. 


\section{PATIK : JURNAL HUKUM Vol : 10 No. 1 April 2021, Hal 61 - 68}

Untuk keperluan pendaftaran hak atas tanah, maka diperlukan pembuktian hak dengan cara: untuk hak atas tanah yang baru, harus dibuktikan dengan keputusanpemberian hak dari pejabat yang berwenang, apabila hak tersebut berasal dari tanahnegara. Untuk tanah Hak Milik, HGB, HGU dan Hak Pakai atas tanah negaradibuktikan dengan akta PPAT.

c) Sertifikat.

Sertipikat merupakan surat tanda bukti hak yang berlaku sebagai alat pembuktianyang kuat mengenai data fisik dan data yuridis, yang data di dalamnya sesuaidengan surat ukur dan buku tanah.

d) Penyajian Data Fisik dan Yuridis.

Rangka penyajian data fisik dan data yuridis atas tanah, BPN/Kantor Pertanahanmenyelenggarakan tata usaha pendaftaran tanah dalam daftar umum. Penyajian datafisik dan data yuridis dimaksudkan agar setiap orang berkepentingan mengetahuidata fisik dan data yuridis atas suatu tanah. Bagi instansi tertentu hal ini dapatmendukung kelancaran pelaksanaan tugasnya. Tata cara dan persyaratan untukmemperoleh keterangan tentang data fisik dan data yuridis ditetapkan oleh Menteri.

e) Penyimpanan Daflar Umum dan Dokumen.

Penyimpanan daftar umum dan dokumen-dokumen yang digunakan sebagai dasarpendaftaran hak tanah, disimpan di kantor BPN/Kantor Pertanahan, orang ataupuninstansi yang berkepentingan untuk memeriksa dokumen tanah yang menyangkutdata fisik dan data yuridis maka pemeriksaan tersebut wajib dilakukan di Kantor BPN/Kantor Pertanahan.

Penerbitan sertipikat dimaksudkan agar pemegang hak dapat dengan mudah membuktikan haknya. Oleh sebab itu sertipikat merupakan alat buktian yang kuat sebagaimana dinyatakan dalam Pasal 19 ayat (2) huruf c UUPA. Hal ini juga diperkuat dalam Pasal 32 ayat (1) PP Nomor 24 Tahun 1997 yang menyebutkan bahwa sertipikat merupakan surat tanda bukti hak yang berlaku sebagai alat pembuktian yang kuat mengenai data fisik dan data yuridis yang termuat didalamnya, sepanjang data fisik dan data yuridis tersebut sesuai dengan data yang ada dalam surat ukur dan buku tanah hak yang bersangkutan.

Namun, walaupun demikian tingginya kedudukan sertipikat hak atas tanah sebagai alat pembuktian yang kuat tetap saja diperlakukan sebagai alat bukti awal. Hal ini didasari kemungkinan adanya alat bukti pihak lain yang lebih berwenang mengalahkannya. Selain sertipikat hak atas tanah masih ada alat bukti lain yang dapatmenggugurkannya. Sebagaimana yang dikemukakan Moch. Isnaini, bahwa sertipikathak atas tanah bukan merupakan satu-satunya alat bukti yang bersifat mutlak, justrusebaliknya baru merupakan alat bukti awal yang setiap saat dapat digugurkan pihaklain yang terbukti memang lebih berwenang.

Hal ini dipengaruhi oleh sistem pendaftarantanah yang digunakan di Indonesia berupa sistem publikasi negatif yang bertendensi positif. Dalam sistem pendaftaran negatif (stelsel negatif) bertendensi positif, pemerintah tidakmemberikan jaminan atas kepastian hukum terhadap pemegang bukti sah (sertifikat).Pemerintah juga tidak bertanggung jawab atas data dan informasi yang ada di dalamsertifikat hak atas tanah. Data dan informasi dianggap benar sepanjang tidak ada pihak lainyang menggugat.

Permen No 11 Tahun 2016 tentang Penyelesaian Kasus Pertanahan, memberikan perbedaan pengertian antara sengketa, konflik dan perkara pertanahan. Pasal 1 angka 2menyebutkansengketa tanah yang selanjutnya disebut sengketa adalah perselisihan pertanahan antara orang perseorangan, badan hukum, atau lembaga yang tidak berdampak 


\section{PATIK : JURNAL HUKUM Vol : 10 No. 1 April 2021, Hal 61 - 68}

luas. Sedangkan konflik tanah yang selanjutnya disebut konflik adalah perselisihan pertanahan antara orang perseorangan, kelompok, golongan, organisasi, badan hukum, atau lembaga yang mempunyai kecenderungan atau sudah berdampak luas. Dan perkara tanah yang selanjutnya disebut perkara adalah perselisihan pertanahan yang penanganan dan penyelesaiannya melalui lembaga peradilan.

Dari pengertian diatas dapat disimpulkan bahwa sengketa tanah adalah perselisihan pertanahan antara perorangan atau lembaga yang tidak berdampak luas, yang penyelesaiannya bukan melalui lembaga peradilan (non litigasi). Sengketa kepemilikan tanah merupakan perbedaan persepsi, nilai atau pendapat, kepentingan mengenai status penguasaan di atas tanah tertentu yang telah dilekati hak milik oleh pihak tertentu.Sengketa tentang kepemilikan tanah timbul karena masing-masing pihak merasa berhak atas tanah yang menjadi obyek sengketa. Sengketa tentang kepemilikan tanah timbul karena masing-masing pihak merasa berhak atas tanah yang menjadi obyek sengketa.

\section{Metode}

Ruang lingkup penelitian ini adalah bertujuan untuk membatasi permasalahan yang akan dibahas dalam penelitian inidan agar pembahasan tidak mengambang yaitubagaimana peran Badan Pertanahan Nasional dalam penyelesaian sengketa kepemilikan tanah dan bagaimana tindakan pihak yang bersengketa atas peran Badan Pertanahan Nasional.

Jenis sumber data yang digunakan dalam penelitian ini adalah data primer, data skunder, dan data tersier. Penelitian ini termasuk penelitian hukum normatif terapan. Metode pengumpulan data yang dilakukan dalam penelitian ini adalah (1) Wawancara, yaitu diperoleh langsung dengan Bapak Jony Samosir selaku Kepala Seksi Penanganan Masalah dan Pengendalian Pertanahan di Kantor Pertanahan Kabupaten Tapanuli Utara. (2) Studi kepustakaan (library research),yaitu dengan pengumpulan data melalui studi kepustakaan melalui buku-buku, literatur, dokumen dan dengan mempelajari ketentuan perundang-undangan yang relevan dengan penelitian.

Setelah seluruh data yang diperoleh dikumpulkan, selanjutnya akan ditelaah dan di analisis secara kualitatif dengan mempelajari seluruh jawaban kemudian diolah dengan menggunakan metode deduktif yang berpedoman pada peraturan perundang-undangan yang berkaitan dengan tanah dan selanjutnya dilakukan pembahasan untuk menyelesaikan masalah yang ada. Metode analisis data yang digunakanini adalah metode yuridis deskriptif yaitu dengan melihat kenyataan-kenyataan yang ada di dalam masyarakat kemudian dikaitkan dengan peraturan perundang-undangan yang berlaku saat ini tentang sengketa kepemilikan tanah.

\section{Pembahasan Dan Hasil} berperan :

Dalam penyelesaian sengketa kepemilikan tanah, Badan Pertanahan Nasional

a) Menampung pengaduan masyarakat terhadap sengketa kepemilikan tanah

b) Mengumpulkan data-data yang diperlukan yang berkaitan dengan sengketa, yang dapat mempengaruhi serta memperjelas duduk persoalan sengketa. Baik data fisk maupun data yuridis dan data lainnya yang terkait.

c) Menganalisis data yang ada untuk mengetahui duduk sengketa dengan jelas dan untuk mengetahui faktor penyebab sengketa tersebut. 


\section{PATIK : JURNAL HUKUM Vol : 10 No. 1 April 2021, Hal 61 - 68}

d) Menerbitkan keputusan penyelesaian sengketa baik keputusan pembatalan hak, keputusan pembatalan sertipikat apabila terbukti terdapat cacat adminstrasi pada saat penerbitan sertipikat.

e) Memberikan mediasi dan fasilitasi kepada pihak yang bersengekata dan menggagas suatu kesepakatan diantara para pihak.

Pasal 4 Pemen Nomor 11 menyebutkan bahwa penyelesaian sengketa kepemilikan tanah dari (1) Pengaduan Masyarakat, (2) Periksa Kelengkapan Berkas Pengaduan, (3) Register Pengaduan, (4) Pengumpulan Data dan Analisis (5) Pengkajian dan Pemeriksaan Lapangan, (6) Paparan, (7) Laporan Penyelesaian Kasus Pertanahan, (8) Penyelesaian, (9) Pelaksanaan Keputusan Penyelesaian, (10) Mediasi.

Tindakan Pihak yang Bersengketa atas Peran Badan Pertanahan Nasional diantaranya adalah:

(1) Menyepakati atas Peran Badan Pertanahan Nasional.

Dalam proses penyelesaian sengketa, tentu menimbulkan dua opsi yaitu berhasil diselesaikan dan/atau tidak berhasil diselesaikannya sengketa tersebut. Dalam hal sengketa berhasil diselesaikan berarti pihak yang bersengketa menyepakati penyelesaian yang dilakukan di Kantor Badan Pertanahan Nasional, para pihak yang bersengketa berhasil menemukan kesepakatan, menyatukan pendapat serta kepentingan mereka yang akhirnya dibuat Perjanjian Perdamaian, yang mengikat bagi kedua belah pihak.

(2) Menolak Atas Peran Badan Pertanahan Nasional

Penyelesaian yang dilakukan di Kantor Badan Pertanahan Nasional dapat juga tidak berhasi diselesaikan, para pihak menolak penyelesaian yang dilakukan di Kantor Badan Pertanahan Nasional.Sebagai lembaga pertanahan, Badan PertanahanNasional tentu tidak lepas dari berbagai kendala-kendala yang dialami pada saat upaya penanganan dan penyelesaian sengketa pertanahan. Kendala yang dialami seperti,mediasi mengalami kebuntuan atau deadlock, yangmana kedua belah pihak hadir dalam mediasi dan masingmasingmenjelaskan kronologi sengketa dan keinginnya, namun kedua belahpihak dengan bantuan mediator tidak dapat menghasilkan solusi yangmemberi keputusan sehingga sulit untuk menghasilkan kesepakatan.Kemudian kendala dariemosi para pihak dalam menyampaikan pendapatnya sehingga memicu emosi kepada pihak yang lain. Sengketa yang tidak berhasil diselesaikan diKantor Badan Pertanahan Nasional, dan kemudian dilanjutkan ke Pengadilan maka hal tersebut tidak lagi sengketa namun perkara. Hal ini sesuai dengan ketentuan Permen 11 Tahun 2016, dimana terdapat perbedaan sengketa dan perkara. Perkara adalah perselisihan pertanahan yang penanganan dan penyelesaiannya melalui lembaga peradilan.Pihak yang bersengketa dapat mengajukan gugatannya ke Pengadilan dengan memuat :

a. Identitas para pihak (penggugat dan tergugat)

b. Dalil-dalil konkret tentang adanya hubungan hukum yang merupakan dasar serta alasan dari penuntutan atau yang lebih dikenal dengan fundamental petendi atau posita moddelen van den eis.

c. Petitum atau tuntutan yaitu apa yang penggugat minta atau harapkan agar diputuskan oleh hakim.

Kemudian penyelesaiannya diserahkan ke pada Pengadilan berdasarkan Hukum Acara yang berlaku. 


\section{Kesimpulan Dan Saran}

Berdasarkan hasil penelitian dan pembahasan pada bab sebelumnya, maka dapat ditarik kesimpulan dari penelitian sebagai berikut:

1. Peran Badan Pertanahan Nasional dalam penyelesaian sengketa kepemilikan tanah diatur dalam Peraturan Menteri Agraria dan Tata Ruang/ Kepala Badan Pertanahan Nasional Nomor 11 Tahun 2016 tentang Penyelesaian Kasus Pertanahan. Peran Badan Pertanahan Nasional dalam penyelesaiannya adalah dimulai dari menerima pengaduan darimasyarakat,kemudian melakukan pengumpulan data dan menganalisissengketa,sertamengkaji dan melakukan pemeriksaan lapangan.Kemudian menerbitkan keputusan penyelesaian sengketa berupa Keputusan Pembatalan Hak atau Keputusan Pembatalan Sertipikat apabila terbukti terdapat cacat adminstrasi. Badan Pertanahan Nasional juga berperan memberikan falitasi mediasi kepada pihak yang bersengketa apabila sengketa tersebut dipandang memungkinksn untuk diadakanmediasi. Hasil mediasi dibuat Perjanjian Perdamaian dan didaftarkan pada Kepaniteraan Pengadilan Negeri setempat sehingga mempunyai kekuatan hukum mengikat kepada pihak yang bersengeketa.

2. Tindakan pihak yang bersengeketa atas peran Badan Pertanahan Nasional dalam penyelesaian sengketa yaitu menyepakati dan/atau menolak. Dalam hal pihak yang bersengketa menyepakati penyelesaian yang dilakukan di Kantor Badan Pertanahan Nasional, berarti sengketa berhasil diselesaikan, para pihak berhasil menemukan kesepakatan, menyatukan pendapat serta kepentingan mereka yang akhirnya dibuat Perjanjian Perdamaian, yang mengikat bagi kedua belah.Pihak yang bersengketa juga dapat menolak penyelesaian yang dilakukan di Kantor Pertanahan, berarti sengketa tidak berhasil diselesaikan, kedua belah pihak tidak dapat menghasilkan kesepakatan. Dalam hal penyelesaian yang dilakukan di Kantor Badan Pertanahan Nasional tidak berhasil diselesaikan, maka sesuai dengan Pasal 37 Permen No 11 Tahun 2016, penyelesaiannya diserahkan kepada para pihak yang bersengketa sesuai dengan ketentuan perundang-undangan. Penyelesaian dapat ditempuh melalui lembaga peradilan.

Berdasarkan penelitian dan uraian dalam pembahasan serta kesimpulan, maka diberikan saran-saran sebagaimana berikut :

1. Hendaknya Badan Pertanahan Nasional dalam hal penerbitan sertipikat, tidak bersifat pasif, namun menyelidiki kebenaran data-data yang diserahkan kepadanya. Hal ini untuk meminimalisir terjadi sengketa pertanahan.

2. Untuk mengantisipasi sengketa pertanahan yang semakin kompleks dan meminimalkan timbulnya sengketa pertanahan dalam masyarakat,maka Badan Pertanahan Nasional untuk kedepan hendaknya lebih proakfif dalam penyelesaian sengketa pertanahan, tidak bersifat pasif /menunggu keinginan para pihak yang bersengketa.

\section{DAFTAR PUSTAKA}

\section{Buku}

Abdulkadir Muhamad, 2004, Hukum dan Penelitian Hukum, PT.Citra Aditya Bakti, Bandung

Adrian Sutedi, 2011, Sertifkat Hak Atas Tanah, Sinar Grafika, Jakarta 
Boedi Harsono, 2008, Hukum Agraria Indonesia: Sejarah Pembentukan Undang-Undang Pokok Agraria, Isi dan Pelaksanaannya, Djambatan, Jakarta

Florianus Sangsun SP, 2007, Tata Cara Mengurus Sertfikat Tanah, Visimedia, Jakarta

Siallagan, Haposan dan Simamora, Janpatar., Hukum Tata Negara Indonesia, Medan: UD. Sabar, 2011.

Irawan Soerodjo, 2003, Kepastian Hukum Hak Atas Tanah Di Indonesia, Arkola, Surabaya Peter Mahmud Marzuki, 2014, Penelitian Hukum, Kencana, Jakarta

Samun Ismaya, 2019, Penyelesaian Kasus Pertanahan, Suluh Media, Yogyakarta

Urip Santoso, 2010, Pendaftaran dan Peralihan Hak Atas Tanah, Kencana, Jakarta

\section{Jurnal}

Kiki Ratna Patricia Siregar, Perlindungan Hukum Terhadap Pemilik Hak Atas Tanah Yang Telah Diterbitkan Sertifikatnya Atas Nama Pihak Lain,

Andi Sitti Saidah Nurfaradiba, Abrar Saleng, Andi Tenrifamauri, 2018, Peran Kantor Badan Pertanahan Nasional Dalam Menyelesaikan Sengketa Pertanahan Melalui Mediasi Sesuai Dengan Peraturan Menteri Agraria Dan Tata Ruang/Kepala Badan Pertanahan Nasional Nomor 11 Tahun 2016, Jurnal, Vol. 1 No. 2, April.

Fingli A. Wowor, 2014, Fungsi Badan Pertanahan Nasional Terhadap Penyelesaian Sengketa Tanah, JurnalLex Privatum, Vol. I No. 2, April

Nia Kurniati dan Efa Laela Fakhriah, 2017, BPN Sebagai Mediator Dalam Penyelesaian Sengketa Tanah Di Indonesia Pasca Perkaban No. 11 Tahun 2016, Jurnal Sosiohumaniora, Vol. 19 No. 2, Juli

Simamora, Janpatar., Tafsir Makna Negara Hukum dalam Perspektif Undang-Undang Dasar Negara Republik Indonesia Tahun 1945, Jurnal Dinamika Hukum FH Universitas Jenderal Soedirman, Vol. 14 No. 3 September 2014.

Estevina Pangemanan, 2013, Upaya Penyelesaian Sengketa Kepemilikan Hak Atas Tanah, JurnalLex Privatum, Vol. I No. 4, Oktober

\section{Peraturan Perundang-undangan}

Undang-Undang No 5 Tahun 1960 tentang Peraturan Dasar Pokok-Pokok Agraria

Peraturan Pemerintah Republik Indonesia Nomor 24 Tahun 1997 tentang Pendaftaran Tanah

Peraturan Presiden Republik Indonesia Nomor 20 Tahun 2015 tentang Badan Pertanahan Nasional

Peraturan Menteri Negara Agraria/ Kepala Badan Pertanahan Nasional Nomor 3 Tahun 1997 tentang Ketentuan Pelaksanaan Peraturan Pemerintah Nomor 24 Tahun 1997 tentang Pendaftaran Tanah

Keputusan Kepala Badan Pertanahan Nasional Republik Indonesia Nomor 34 Tahun 2007 tentang Petunjuk Teknis Penanganan dan Penyelesaian Masalah Pertanahan

Peraturan Menteri Agraria dan Tata Ruang/ Kepala Badan Pertanahan Nasional Republik Indonesia Nomor 11 Tahun 2016 tentang Penyelesaian Kasus Pertanahan 